\title{
Research on Teaching Mode of College Physical Education under the People-oriented View
}

\author{
ZiXin Zhu ${ }^{1, a}$ \\ ${ }^{1}$ Physical Education Department of Hua zhong Agriculture university ,Wuhan \\ 430070, China \\ aemail: Imc-107@mail.hzau.edu.cn,
}

Keywords: people-oriented, teaching mode, college physical education, individual mental characteristics

\begin{abstract}
Teaching concept of physical education is the deeply hidden soul and essence of the teaching mode of physical education. It determines the direction and effectiveness of the teaching mode of physical education. Based on a further demonstration of people-oriented View, this essay will analyze the current teaching mode of college physical education from the angle of the social and individual development needs. College physical education should pay full respect to students' interests, emotion, dignity, individual mental characteristics, etc. Thus to better implement and fulfill the People-oriented Education Concept
\end{abstract}

\section{Introduction}

Physical education concerns not only about simple questions like the health of body, but also about matters like mental health and a sound social adaptation. Physical education can create and enrich human culture, and improve people's living quality. What's more, physical education also optimizes mind and personality, cares about people's existence and value, as well as promotes people's freedom and happiness. ${ }^{[1]}$ College physical education, by the processes of teaching and learning, makes itself transfer into student's psychological quality, values, cultural personality, etc. While as the core of the Scientific Development Concept of Education, people-orientation, to a large extent, belongs in philosophical exploration and has become a basic concept of today's education careers, and it appears extremely significant in today's college physical education.

\section{Definitions of people-oriented education concept and teaching mode}

People-orientation means that people should be regarded as the priority before everything and that people is the only one who needs to be cared about most. ${ }^{[2]}$ In terms of the relationship among nature, society and people, people takes the highest position and everything is for the sake of people. In the field of education, people-orientation means taking people's overall development as the starting point of education and the evaluation standard of the functions of education. To be specific, the final ideal of education is whether people's potential has gained fully development, whether people's individuality has completely presented, and whether people's personality has got freedom. Generally speaking, people-orientation has two levels of meanings. One is that people is the promoter of social development and the creator of world; people owns wisdom and ability to reform the world and promote social development. The other is that people's personality, individuality and personal value should be fully respected, which, in a word, is taking individualism and self-dignity as life value. People-orientation, when put in the specific teaching and learning process of college physical education, should best highlight humanistic care. Both physical education managers and teachers should concern about the differences of students' physical condition and features of their personality and minds as well as their emotional requests, thus to adopt different teaching methods in accordance with students' differences. Through this, physical education can better put use of its various functions such as improving physical fitness, adjusting emotion and psychology, completing personality and promoting social interaction and adaptation. 
Up to now, different people has expressed different understandings on the definition of teaching mode. Teaching mode was first brought out by American scholars like Joyce and Will. They held that teaching mode is a series selectable models which tries to systematically study interrelations among the aims of education, teaching strategies, curriculum design, teaching materials and social and psychological theories, The teaching mode of physical education, based on certain teaching theory of physical education, is a relatively stable teaching structure. What worths mentioning is that teaching ideal plays a key role in setting out a teaching mode because the design of teaching mode is always based on a certain kind of teaching thought or ideal.

\section{People -oriented teaching concept in the teaching mode of college physical education}

In the traditional teaching and learning process of college physical education, teacher plays the dominant role while students are in a negative learning state, with features that students learn what the teacher teach and students learn according to how the teacher teach. This teaching concept reflects college physical education mainly from the aspect of "educating people", that is, what type of people the society needs, school will cultivate what type of talents, and accordingly, college physical education will apply directed education for students in accordance with the social needs. However, although having seized the social needs, this cultivating mode, at the same time, have neglected its educating objects---every student has right to choose his own way of development. People-oriented teaching concept emphasizes that education should first take people as the education purpose and value. It also stresses that education will serve for fostering people and take development of people, realization of people's value, exploration of people's potentials as well as the development of people's personality as the education goal. The education process, on the one side, is to satisfy the external needs of social development for talents; and on the other side, is to meet students' innate, spiritual, moral and mental needs. People-oriented teaching concept connects education with people's happiness, freedom, dignity and value, uses humanistic spirit to foster modern people and takes a comprehensive and developmental horizon to cultivate allround developed people, with the purpose of promoting the reformation and development of physical education and educating a comprehensive people who can both meet the social needs and his own development. College physical education owns a dual function of physical fitness and education. Its main functions include bodybuilding, moral education, intelligence inspiration, aesthetic education, entertainment, developing students' sentiment, etc. College physical education is not only a main way to develop students' body quality and physical health, but also an indispensable approach to carry out literacy education, affection education, social adaptation education and so forth for students.

\section{Analysis on the existing teaching mode of college physical education}

Along with the development of educational reform of college physical education, a majority of colleges have carried out new measures which meet the needs of social development. And new teaching modes appear during the continuous explorations and researches. Based on their stereotypical knowledge on traditional physical education and the limits of the traditional teaching mode of it, some colleges still attach importance to the organization and discipline of teaching, stress the logic and ration of it and emphasize the order and unity of learning as well. However, this authority-upholding unity makes students lack of individuality and creativity. It also dose not well realize people-orientation. At the same time, the unite syllabus emphasizes unity so much that it appears lack of flexibility, which can not adapt individual development. What's more, both extra-curricular activities and PE course are regarded as orthodox and the obedience of students is treated as normal. They stress rigorous organization and discipline, emphasize teacher's dominant positon and function, and think highly of “three basic" in teaching process. They also ignore students' active participation. Students are so busy 
listening to the lecture, watching the instruction and doing practices that they have no time to enjoy the pleasure of fitness exercises.

\section{A. “Three-phase Type” Teaching Mode of Physical Education}

Generally speaking, "three-phase type” teaching mode opens basic courses for freshmen, In the practice of physical education, teachers are still in the dominant position. While students' interests will be satisficed to some extent, their principle position can not be fully realized in the learning process. The advantages of "three-phase type" teaching mode lie on that it emphasizes not only students' foundation of sports and promotion of constitution, but also the cultivation of students' sports ability and physical exercise habits. Seen from the reform and development course of our country's physical education, "three-phase type" teaching mode has now become one of the main teaching modes of our country's college physical education. ${ }^{[3]}$

\section{B. "Elective Course Type” Teaching Mode}

The teaching guidelines of “elective course type" teaching mode are fully respect students' rights of choosing sports programs and train students' sports ability and physical exercise habits based on their interests. Its teaching organizing form is that the courses for both freshmen and sophomores are elective courses; its teaching contents are mainly setted according to students' interests, which can provide them abundant selectable sports programs.

\section{C.“Club Type” Teaching Mode}

The organizational form of "club type" teaching mode is special sports club. It enables students to choose sports club freely, to manage their own activity time and attends given activities of the club. This teaching mode takes fostering students' love and interest of sports as guideline and makes the improvement of students' sports ability and cultivation of their habits of voluntarily taking part in sports exercises as goal.

\section{Enlightenment of people -oriented education concept on the teaching mode reform of college physical education}

\section{A.The Teaching Mode of Physical Education should Focus on Cultivating Students' Team Spirit, Social Adaptation and Social Intercourse Ability.}

People is a higher being of society. Therefore, people must be the man in society. By educating students' intelligence, social identity and their personal role in society, college physical education promotes the socialization of students' personality and to form their sound social adaptation. Cooperation and competition are the main actions of people' social interaction. They are also a must quality of modern college students. In the teaching process of college physical education, the teacher gives full play to class organization forms like small group and cooperative teaching to train students' cooperation spirit and ability. In this way, a benign competition among students and their common development can be realized; students’ social interaction ability can be improve.

\section{B.The Teaching Mode of Physical Education should be Transformed from Teaching one What to Teaching one how to Learn}

College physical education should try hard to make students understand and grab the basic knowledge and skill of physical fitness and nutrition, train their lifelong sports consciousness and promote their formation of sports interests and benign sports and health habits. In order to achieve the teaching idea "health comes first" and carry out people-orientation teaching concept, physical education teaching mode should not only focus on students' on-class learning but also on the cultivation of their independent learning out of class, thus to realize a harmonious development. This should be the ultimate goal of physical education. Moreover, physical education should also foster and improve college students' sports cultural accomplishment and make them both participate sports events and know sports events, sports spirit, and sports history. Only if students understand sports can they better love and then do it. Therefore, it is urged that physical education transforms from "instructing function" to "developing function", with teachers playing the leading role and students' 
ability of self-learning being trained. This transformation gives full play to students' operational ability and trains their independent learning awareness and ability by the realization of teachers' "teach" to "not teach" and students' "can not learn" to "can learn". And when students own the learning awareness and ability, they will better do physical fitness activities.

\section{The Teaching Mode of Physical Education should Cultivate Students’ Personality and Comply with "Students' Comprehensive Development"}

Physical education is a significant part of education. Looking back at the education reforms, "for the evaluation of function, we should change the one-sided social-only value or the one-sided subject-only value into the subject value which fully respect people under the premise of meeting the needs of social development" ${ }^{\text {"4] }}$ one will find that these reforms mainly follow the following two directions: one was to adapt to the external social development; the other is to fulfill he internal people's spiritual, psychological and moral needs.college physical education is a an educational process which highly unite humanistic spirit with physical acts. To make physical education become a true "students' comprehensive development" education, measures like follows should be taken: setts body movement as means and respect of people's comprehensive development as goal; makes people-orientation education concept run through every segment of college physical education; brings physical education's value and function on educating people; and fully respects students' interests, affection, personal characters, etc.

\section{Conclusion}

As a new education concept, people-orientation has distinctive features as rationalization, targeting and systematization in college physical education practice. It effectively guides college physical education. More importantly, it makes people-orientation as the starting point and destination of physical education and has built the firm belief of completely achieving physical education's goals in the new period. During the reform and selection of the teaching mode of college physical education, respects to college students' personality, mind, freedom, human rights and value should be stressed in the whole process of teaching. "Physical education should focus on students' personality and make it gain full and natural expression during body activities and trainings. What physical education brings to students should be the pleasure and happiness from body to mind, which is a kind of free flow of humanity and a kind of thorough release of emotion. And this needs us to understand the true meaning of physical education from the angle of people. People is forever the starting point and destination of physical education."[5] Implementing the people-orientation education concept is the fundamental way to realize the comprehensive development of people and the return of physical education's essential functions. Acknowledgement

\section{References}

[1] Wei Cao; The Modern Physical Education View of Establishing Center around the Human Being; [J] China Sport Science; April,2004; pp67-69

[2] Liping Wang; “Student-oriented” Educational Ideology and University P.E. Curricular Reform [J] Journal of Wuhan Institute of Physical Education; November, 2006, pp106-109

[3] Mingchang Liu; Study on the Curriculum Arrangement and Teaching Mode of University Physical Education in Wuhan; [D] Nanjing Normal University, dissertation for master degree in 2007

[4] Enyuan Pan ; the transformation of higher education thought stepping into the 21th century [J] Liaoning Higher Education Research, June 1998

[5] Haiqiang Yuan, Xinrong Zuo; Integration of People-orientation and Cultivation-orientation in Physical Education; [J] Journal of Beijing University of Physical Education; July, 2004; p952-954. 